\title{
最近の歯学
}

\section{4. 口腔外科}

\section{最近のペニシリン系抗生物質}

\author{
第一口腔外科学教室道健而
}

ペニシリンは 1928 年 Fleming によつて発見され, 1941 年に臨床使用に供されるようになつて一時はペニ シリン厅能の時代があつたが, やがて, 耐性菌が増加 し, ショックの発生があいついで報告されると, その使 用頻度が急激に低下し, 他の抗生物質が好んで使われる ようになつた。他方, 1957 年に Sheehan らによつて ペニシリンの合成に成功して以来, 各種の内服用ペニシ リンが次々と作られるようになると, 耐性菌用ペニシリ ンが出現し, ペニシリン・ショックもその発生頻度が低 下して再びペニシリンの適応範囲が広くなり再評価の 時期を迎えている。

そこで, 現在われわれが使用しているペニシリン剂を まとめてみる。

ペニシリンの利点は第 1 にブドウ球菌, 連鎖球菌など のグラム陽性菌に対して, 他の抗生物質よりもはるかに 強力な制菌力を有することである。例えばクロラムフェ ニコールと比較すると $1 / 50$ 1/100 の濃度で同一の効果を 発揮するという報告がある。第 2 には長期間大量に使用 しても毒性がほとんど皆無であるということで, アレル ギー反応以外の副作用はきわめて稀であり，わずかに非 常に大量に投与した場合に貧血を起こした 2 例, 脳障害 を起こした 1 例が国外で報告されている程度である。

最も恐れられているペニシリン・ショックの対策と

して,われわれは外来患者で内服投与をする場合には問 診を主体とし, 筋注の場合あるいは内服投与でも必要と 思われる時にはペニシリン・テスト液 25 単位 $0.05 \mathrm{ml}$ を皮内注射して 15 分および 30 分後の皮膚反応を見て 判定しているが，最近は特に事故を起こしたことはな い。

現在使用されているペニシリンは抗菌範囲の相違か ら3つの群に分けて考えられている。

第 1 群は従来からある天然ペニシリンおよび，これと 同じ抗菌範囲をもつ合成ペニシリンである。天然ペニシ リンとしては Penicillin G が今でもなお使用され，合 成ペニシリンとしては, 耐酸性の内服可能なペニシリン である Phenoxy-ethyl-penicillin（シンシリン・万有, シンセペン・明治, マキシペン・台糖), Phenoxy-propyl-penicillin (シンセペンP・明治, トレスシリン・藤 沢)がある。投与量は Penicillin G では 1 日 60 万単位 の筋注, 合成ペニシリンでは 1 日 $120 \sim 160$ 万単位また は $1.5 \sim 2.0 \mathrm{~g}$ を $4 \sim 6$ 時間毎内服が普通である。この 群はペニシリンの中でも制菌力が特に強いので現在で も放線菌症に対して，われわれは 1 日 120 万単位程度の
連続筋注投与を行なつて効果を上げている。

第 2 群は耐性ブドウ球菌用ペニシリンで, いわゆるぺ ニシリン耐性ブドウ球菌のもつ Penicillinase によつて 分解されず同菌に対しても制菌作用をもつものである。 制菌力は感受性菌に対しては Penicillin G の約 $1 / 10$ で, 耐性菌に対してはマクロライド系抗生物質と大体同等 である。この群には構造式の 異なる数種のものがある が, Methyl-phenyl-isoxazolyl-penicillin（スタフシリン $\mathrm{V}$ ・ 万有), Methyl-chlorphenyl-isoxazolyl-penicillin (メ トシリン $\mathrm{S}$ ・明治, オルベニン・藤沢）などをわれわれ は使用している。従来のペニリシンと比較すると 250 $\mathrm{mg}$ が約 40 万単位に相当するといわれていて, 投与法 は内服で 1 日 1.5 2.0 g を 4 6 時間毎に, 筋注では $1.0 \mathrm{~g}$ を朝夕 2 回に分けている。われわれは顎骨々髄炎 の治療, 術後の感染予防に最も多く使用しているが. 急 性炎症の症例では無効例は非常に少ない。

第 3 群は耐性ブドウ球菌には効果がないが, 抗菌範囲 が広く，グラム陰性菌にも制菌作用をもつものである。 現在，わが国には，Aminobenzyl-penicillin（ビクシリ ン・明治, ペントレックス・万有, ペンブリチン・藤沢) がある。ブドウ球菌に対する効果は Penicillin G の約 $1 / 10$ といわれているが, 赤痢菌やサルモネラにも有効で あり, 大腸菌に対しても菌株によつて低濃度で制菌力を 発揮する点で注目されている。われわれの領域でも混合 感染の考えられる場合には有効な薬剤であり, クロラム フェニコールやテトラサイクリンに代えてしばしば使 用している。投与法は注射, 内服とも前 2 群と同様で, 内服では 1 日 $1.5 \sim 2.0 \mathrm{~g}$ を 6 時間毎に，笳注では 1 日 $1.0 \mathrm{~g}$ を朝夕 2 回に分けている。副作用は他のぺ ニシリンと同様にアレルギー反応だけといわれている が，われわれの経験では Methyl-phenyl-isoxazolyl penicillin などと比較して発疹を起こす症例が多いようで ある。

以上，ペニシリン系抗生物質について要約したが，口 腔外科領域の抗生物質の使い方を考えてみると, この領 域の感染症ではその起炎菌のほとんどはグラム陽性菌 であるため,これらの菌に特に制菌力の強いものを中心 にして使うことになる。すなわち, ペニシリン系あるい はマクロライド系の薬剤が主体となり, クロラムフェニ コールあるいはテトラサイクリン系は第 2 次的なもの となる。この様な理由でわれわれは現在でも多くの症例 にペニリシン系抗生物質を使用している。 